\title{
A Proposal for Revitalizing Some Ancient Egyptian Festivals for Tourists' Attraction
}

\author{
Ghada Mohamed Bassiony Tarneem Farag Bayoumy
}

Higher Institute of Tourism, Hotels and Computer - El-Seyouf, Alexandria

\begin{abstract}
Festival is a special event which is a public themed celebration based on specific themes. Festival Tourism plays an important role in the current tourism activities. The ancient Egyptians celebrated various festivals throughout the year, some of which were related to the king, others to the Nile and agricultural life, while the majority was related to their gods. The purpose of most of these festivals was to allow the people to behold their gods with their own eyes. This paper aims at investigating some of these festivals in regards to the possibility of revitalizing them as a means of tourists' attraction.To serve the purpose of the study questionnaires were distributed among travel agencies, tourists' authority and tourists. The study revealed that there is a will to organize them from tourists' authority, and a will from travel agencies to involve them in tourists programs. The study ends with suggestions and a special agenda of these festivals throughout the year.
\end{abstract}

Keywords: Proposal-Festivals, Revitalizing- Tourists’ Attraction, Tourists Authority

\section{Literature review}

\section{The touristic importance of festivals}

\subsection{The basic concept of the festival}

There are different definitions of festivals in literature. It is a kind of social activity according to the needs of people and has been gradually established and passed from generation to generation ${ }^{[1]}$. Festival is a special event which is a public themed celebration based on specific themes often characterized as follows: 1) They often have their departure in hobbies, 2) they engage (a large) voluntary workforce at low or no labour cost, 3) they can develop from being local to becoming regional, national, international and global, 4) they include both non-profit and profit business, 5) many festivals are open air events. Often being conceived by individuals with a passion for the specific art form presented, it is not until they grow to a certain size that they begin to make use of professional management skills, and consider a systematically data collection. Thus, information on the economic impact of many small or mid-size festivals are lacking $^{[2]}$.

The implication of the overview of festivals seen in a specific perspective is that, general festival management in relation to festivals with a specific perspective only exists to a limited extent and only if or when the festivals become institutions in the society. Furthermore, many festivals have both private and public stakeholders, but festival managers initially tend to lack specific skills in combining private and public interests. As a consequence, the public support and subsidies to such festivals are often the result of political interests in the festival activities ${ }^{[2] .}$

\subsection{Festivals as tourists' assets}

Festivals play an important role in tourism. Many authors ${ }^{[3,4,5,6,7,8]}$. believe that festivals are tourist assets. Moreover, festivals are also treated as tourist products ${ }^{[7,8]}$.

In Getz' works ${ }^{[9,10]}$, the tourism, where the aim is to attend festivals, is treated as a part of event tourism. Cudny et al. ${ }^{[11]}$ treat travelling to festivals in a similar way, and believe that festivals are one of the most important goals of tourist trips within event tourism. This, in turn, Cudny et al ${ }^{11}$ treat festivals as a form of cultural tourism, in which people travel to different events. Kowalczyk ${ }^{[12]}$ gave a geographical definition of cultural tourism, stating that it is "a set of behaviours connected with tourists' authentic interest in cultural heritage (historical monuments, folklore, sites of important events, etc.), as well as to their participation in a broadly understood contemporary cultural life".

Kowalczyk $^{12}$ distinguished several forms of cultural tourism understood in this way. One of them is cultural-artistic tourism, which may include trips to festivals and other cultural and art events. According to Mika ${ }^{[13]}$, tourism where the main motive is the participation in cultural events, such as film, theatre, music, street festivals, or other events related to entertainment, fun and sport, should be considered separately and referred to as festival tourism.

In a geographical article by Cudny ${ }^{6}$, festival tourism is treated not only as cultural tourism, but also as urban and rural tourism. He believes that festival tourism should be treated as a separate type of tourism, because what attracts tourists in this case is a particular tourist asset, namely the festival. Festivals should be understood as organized events, representing different emanations of human culture, during which people meet irrespective of their work (except business and sports meetings). Tourists travelling in order to attend festivals should be called festival tourists. The process of festival development and their increasing influence on their surroundings is referred to as "festivalization"11. So researchers agree that festivals attract tourists and create festival tourism. Tourists are attracted by many elements, 
the most important of which seems to be interesting, sometimes exotic culture, presented during the events ${ }^{[14]}$. Besides, tourists want to attend events of unusual atmosphere, meet people of similar interests, and learn more about the world.

Due to the fact that festivals generate tourist traffic, they have an influence on a number of elements of the surrounding space. In this context, a separate type of space is identified, called tourist space. As festival tourism modifies the physical, social and economic aspect of space, festivals are also the object of study in tourism geography. Currently, in many countries festivals are visibly developing and the significance of festival tourism is rising. At the same time, researchers, even those who represent tourism geography, are not showing any particular interest in these issues ${ }^{[15]}$.

Festival Tourism plays an important role in the current tourism activities. Most people will especially travel to attend a festival. Therefore, festival tourism activities can be arranged in a reasonable time so that it can help the area be one of top destinations. In the local culture, the Festival Tourism has played an active role to enhance urban functions and shape tourism image to attract tourists ${ }^{[16]}$.

\subsection{Festivals contribution to tourism development}

Local festivals are increasingly being used as instruments for promoting tourism and boosting the regional economy. This is often reflected on the level of public assistance made available to them. The use of festivals as an instrument for tourism development has gained worldwide momentum in recent years. New festivals have been invented and promoted for the purpose of drawing new visitors to a city or region and increase the demand for local tourism ${ }^{[17]}$. Successful festivals can help recreate the image of a place or contribute to the exposure of a location trying to get on the tourism $\mathrm{map}^{[18]}$. The strategic placement of a festival in the local tourism calendar can help extend the tourism season ${ }^{[19]}$. When assessing the effect of the festival as a tourism or economic development tool, the standard approach is to invoke some form of impact analysis. In most instances, this involves estimating an aggregate measure of income and employment change attributable to the festival. Invariably, the results are favourable and are then used to bolster the demand for public support for the festival. Events attract visitors, increase the average consumption and length of stay and affect repeated visits of tourists to a certain destination. Different events have the ability to attract visitors in the low season, thereby increase the usage of capacities and provide additional income from tourism. The event is a specific product because it is held usually once a year and has an unusually strong impact on creating the image of a tourist destination ${ }^{[1]}$.

The division of events can be made according to the size, form and content. The size of events is usually determined according to the scale of effects related to the attendance, media coverage, infrastructure, cost and alike. Thus, according to their size, events are classified as: mega-events, hallmark-events, major events and local or community events ${ }^{19}$.

Mega-events are events that have a large impact on the economy of the entire country and have significant presence in the global media. According to their size and importance, they represent those events that have wide media coverage, produce a large impact on the tourist development and contribute to the overall economy of an area or a destination ${ }^{[20]}$.

Hallmark events are those events which have become so identified with the spirit of cities, places or regions that they have become synonyms for the place where they are held. [4,] It is "an event of the distinctive quality of the program, with an authentic setting and performance, due to which it has distinctive characteristics in comparison to other equivalent events." ${ }^{\text {[21] }}$

Major events are those events that attract a substantial number of visitors, have wide media coverage and economic benefits for the areas in which they are held. These events usually have some kind of cultural significance, and can be competitive, musical and may even have a religious content.

Local or community events are intended mainly for local residents and are normally based on local, social and entertaining values. They bring significant benefits to the local community, because they help create a sense of belonging and recognition of the environment ${ }^{[22]}$.

\subsection{Characteristics of the festival tourism}

Authors agree that there are five main characteristics of festival tourism ${ }^{1}$ namely :(1) Local, the host of festival tourism all according to region characteristic culture, custom, geographical location, in various regions, it is unique for every festival activity, that it is unable to copy and replace other places.(2) Participate and Experiential, festival tourism is different from traditional tourism, its participation is one of the significant characteristics of festival activities. (3) Cultural, the development of festival tourism, is not only to activate the tourism market, enrich tourism resources, but also to strengthen cultural communication between countries and regions. (4) Comprehensive, festival tourism has a great correlation, involving political, economic and cultural aspects, which leads to the development of related industries.(5) The Continuity of Benefit, festival tourism as a new form of tourism products, always improve the visibility of the location, drive the development of relevant industries, promote local economic development.

After displaying the importance of festivals for tourists' attraction and their contribution to the tourism development and their impacts on the economy, the following part will display the historical importance of Ancient Egyptian festivals, its purposes, the ancient Egyptian festival calendar and the proposal of revitalizing three of these festivals. 


\section{The historical importance of the ancient Egyptian festivals}

\subsection{Ancient Egyptian festivals}

Egyptians celebrated hundreds of festivals; both local and national at regular intervals, some of them were related to their gods, seen in the festivals of gods Osiris, Isis, Hathor, Amun, Sokar, Thoth and others. Other festivals were political like the $\mathrm{Hb}$-sd festival celebrated by kings after thirty years of rule, coronation of kings, and personal or individual festivals as the annual celebration established by king Ramesses III to honor his victory over the Libyans, and festival of king Amenhotep I for Deir el Medina workforce. There were also seasonal festivals related to the Nile and agriculture as the festival of the Djed pillar that depicted growth and the movement of the sap in the trees as part of rebirth, the festival on the occasion of the annual rising of the Nile, and the harvest festivals. It is worth mentioning that the majority of the previous festivals whether related to gods, kings or the Nile, can include more than one type of festival, for example festivals related to the Nile( seasonal) were also related to gods( religious) like that of the god Osiris, god of agriculture and the god Hapi, god of the Nile. The ancient Egyptian word for festival is ${ }_{\mathrm{Hb}}$ the word is followed by the determinative consisting of a primitive-hut standing on a dish. Both are conventional hieroglyphic signs. The latter sign represents an alabaster dish which was used for purification ceremonies, the former represents the frame -work of a rude-hut, made of reeds and supported by a pole in the middle ${ }^{[23]}$.

\subsection{Sources and purpose of religious festivals}

Some festivals are known only from brief references in letters or graffiti; others are recorded in considerable details in texts and in representations on the walls of temples. Since the earliest times, religious festivals have been held in Egypt ,In the Old Kingdom this is evidenced by the Palermo stone which has a list of the principal religious events during the first five dynasties, among which is the spring festival of Easter, Min and the Hb-sd festival of the pharaoh ${ }^{[24]}$. Unas funerary pyramid texts of the $5^{\text {th }}$ dynasty record festive ceremonies that were performed on the $1^{\text {st }}, 6^{\text {th }}, 15^{\text {th }}$ of every ancient Egyptian month ${ }^{[25]}$. In the Middle Kingdom, sources of festivals include commemorative Stelae left near the temple of Abydos and the stela of nfr-Hr in Saqqara, papyrus rolls at the site of Il-Lahun, feast lists from Beni Hassan as in the tomb of Xnm-htII ${ }^{[26]}$. New Kingdom marks the richest in festival sources, the most known is the festival list of Ramesses III at Madinet habu, festival list of Tuthmosis III at Elephantine, Ramesses II's temple at Abydos, inscription of king Tuthmosis III at the temple of Mut at Karnak, Dynasty 19 rock inscriptions from Gebel el Silsila, on the walls of the temple of Luxor, ostracons from Deir el Medina, and later at Dendarah temple, Edfu, Esna, KomOmbo, Philae ${ }^{[27]}$.

The purpose of most of these festivals was to allow the people to behold their gods with their own eyes and to make mythic traditions assume material reality. Particular images of the gods were carried in portable shrines from the temple sanctuaries and carried through the streets or sailed on the Nile to permit the public to see them and to derive benefits from them that could be received collectively by touching the god or by acquiring images of the gods to evoke the powers of the festival ${ }^{[28,27]}$. Also at festivals, questions were asked of the gods - as long as they could be answered by a "yes" or "no". If the bark (in the hands of the priests) tipped towards the petitioner, the answer was as "yes", if it tilted away, the reverse would be interpreted ${ }^{[29]}$. Thus the function of these festivals was to maintain the essential order of the universe, whereby the gods would grant the conditions necessary for human prosperity in exchange for the requirements of their own existence ${ }^{300}$. Festivals were community affairs, a time for the residents of a village or a town to abandon their daily tasks and come tighter in celebration ${ }^{[31]}$. Festivals also had important social implications, bringing together people from the surrounding region and reinforcing the popular sense of a religious landscape ${ }^{[32]}$.

\subsection{Festivals according to the ancient Egyptian calendar $\left({ }^{[33,34,35]}\right)$}

According to the ancient Egyptians the year was divided into 365 days, distributed among three seasons, every season contained four months, every month 30 days, and the last 5 days of the year, "over the year" were celebrations ${ }^{[36]}$. It is noteworthy that there were two main divisions of feasts: 1- Feasts of heaven (Hbwnwpt), 2- Seasonal feasts (Hbwtptrw), which is as follows:

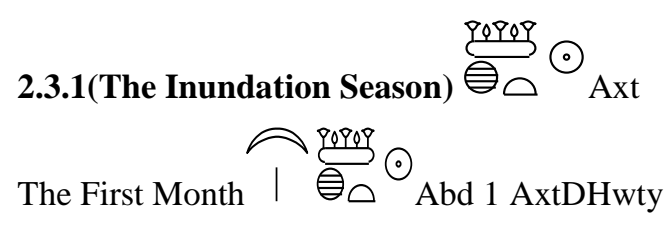

1-“The Opening of The Year Festival”,( beginning of the new year), or wp-rnpt, (Thuthi 1 -July 18)celebrating the rising of Sirius or Sothis in the night sky, shortly after, the Nile responded and the inundation began , mythological by the tears of Isis.Dedicated to the god Hapia great festival took place on the occasion of the annual rising of the Nile, during the ceremony, a statue of the god Hapi was paraded through the towns and villages of ancient Egypt .Anticipation led to a celebration of music and dance where men and women came from all parts of the country to participate ${ }^{29}$..At the festival of Hapi celebrated at Silseleh in Upper Egypt, the officiating priest (sometimes the king himself) sacrificed a bull and geese and a sealed papyrus roll containing a written command to Hapi to flood at the right degree $^{[37]}$. 
2- The Feast of Ankt (Thuthi 7 -July 25), Originated in southern Egypt and was celebrated as early as 4500-5000B.C.E, the two tributaries that fed flood waters to the Nile were thought to be her arms. During inundation these arms reached out to embrace all Egypt's fields ${ }^{33}$.

3- The festival dedicated to Thoth, (August 3-5) and later the feast of Wag became associated with it (first evidence of this celebration is from the $4^{\text {th }}$ dynasty).

4- The Inebriety of Hathor (Thuthi 20- August 7).During this particular festival, alcoholic drinks were in plentiful supply, according to the legend, the feast day was established by the sun god Ra to celebrate the new year, to commemorate the saving of Egypt from the ravaging power of Sekhmet.

The Second Month 11 官口 $\odot$ Abd 2 AxtmnHt (Phaophi- Baba)

1- The feast of Hathor and Min (Phaophi 5- August 22), this southern feast seems to be very ancient, Hathor being the oldest goddess in Egypt and Min being the oldest god predating even Ra. As with any festival in Egypt statues of the god Min and his consort Hathor were paraded through their temples carried on the shoulders of priests in Coptos and Denderah $^{33}$.

2-The Opet Festival (August 31-Sep. 10), which will be discussed in details in the second part of this study.

The Third Monthl I I气 Abd 3 Axt @wt-@rw (Hathor-Athyr)

1- The feast of Hathor (1st day of the month- Sep. 17), celebrated at Dendarah, which was a time of pleasure and intoxication $^{28}$.

2- The feast of the beautiful meeting( sacred marriage of Horus and Hathor), which was held in Edfu at the new moon where the statue of Hathor travelled from Dendarah 100 miles upstream to Edfu where the temple of Horus was located. The two statues were placed side by side for a period of two weeks before the statue of Hathor returned .Many stops were selected at specially chosen sites along the way. At these stops, offerings were made to the deity while incense burned ${ }^{29}$.

3- Feasts related to the goddess Isis (17th-30 ${ }^{\text {th }}$ Hathor- Oct.3-16), in the typical Egyptian story form, 40 days after Isis birthday (17 Oct.) Isis was impregnated ${ }^{25}$. These festivals were distinguished by elaborate decorations, including a temporary shrine with floral bouquets ${ }^{28}$. The feast day of Maat (21Hathor- Oct.8).In the last day of the month was Isis feast in Busiris (30 Hathor- Oct.16) ${ }^{33}$.

The fourth Monthl I I I

1- Hathor feast (17 Khoiak-Nov.2)

2- The feast of Sokar (17-30 Khoiak)

3- Festivals of Osiris, (from the $27^{\text {th }}$ to $30^{\text {th }}$ Khoiak- Nov.12-15), which is the Osiris Mysteries (Isis seeks the body of Osiris, Isis grieves the loss of Osiris, Isis rejoices as she finds Osiris) ${ }^{33}$.

$\square \square \frown$

2.3.2The Peret season $\frown \odot$ prt

The fifth month $\bigcirc$ OAbd 1 prtsf-bdt ( Ta-aabet-Tybi)

-Feasts related to goddesses Hathor and Bastat, Hathor feast (19-20 Tybi- Dec.4-5), celebrating her voyage to Nubia, and on 28-30 Tybi- Dec.13-15, the celebrating of the return of Hathor to Egypt with her father. While on 20 Tybi Dec.5, celebrating Bastat going forth from Bubastis ${ }^{33}$.

The sixth month 1 । $\bigcirc \bigcirc$ Abd 2 prtrkH-wr (Mekhir, Meshir)

1- The feast of the voyage of Hathor and her father continues $\left(1^{\text {st }}-3^{\text {rd }}\right.$ day of the month-Dec.16-18).

2- The feast of Isis, the black cow and the festival of rising the Djed-pillar of Osiris (6th day of the month-Dec.21).

3- The feast of the birth of Ra and Horus (10 $0^{\text {th }}$ day- Dec.25).

4- The feast of the returning of Isis from Phoenicia with Osiris body (19th day-Jan.3).

5- The feast of Hathor visiting her seven sisters (21st- Jan.5).

6- The feast of Isis greeting Min in Coptos (24th- Jan.8). 
The seventh monthl $\mid \subset \bigcirc$ Abd 3 prtrkH-nDs(Pamenot)

- The brilliant festival of the lights of Neith.

\author{
$\curvearrowright \square$ \\ The eighth monthl I I $\mid \frown \odot$ Abd 4 prtrnn-wtt(Parmuti)
}

- The feasts of the blessing of the fleets by Isis (20th of the month-March 5), the feast of Isis giving birth to Horus the younger $\left(28^{\text {th }}\right.$ - March 13). The feast of Renenutet.

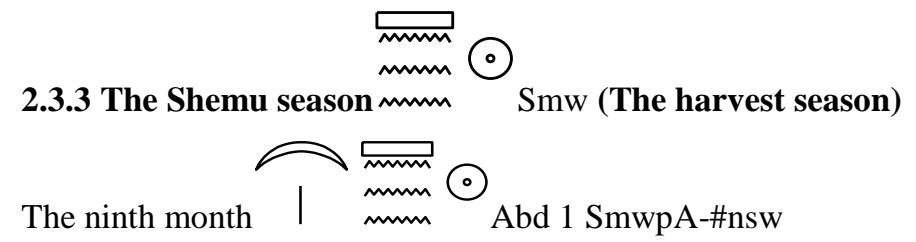

- Among the feasts are: Thefeast of the hand of the god on the $1^{\text {st }}$ day, (March 16), the festival of Renenutet on the $15^{\text {th }}$ of the month (March 30).

The tenth month I I

1- The most important is the festival of Bastat at Bubastis on the $1^{\text {st }}$ day of the month (April15).

2- The feast of the valley, it is one of the earliest of the annual festivals at Thebes ${ }^{[38]}$. Egyptians believed that the cliffs on the west bank of the Nile, was populated by the deceased and protected by Hathor ${ }^{31}$. During the first day of the festival, the procession arrived the necropolis, the musicians made a lot of noise, which enlivened the deceased and caused them to emerge from their tombs to see Amun and to meet with their families. At late day, the procession headed towards Deir el bahri in which Hathor dwelled ${ }^{31}$. During the night, Amun in his ithyphallic form was thought to spend the night with Hathor, their union evoking re-creation and rejuvenation which made the shrine of Deir el bahari a place of pilgrimage for those seeking cures or fertility charms. A lot of people participated, for them the most important aspect was the sensual communication between the living and the dead that took place at the tombs ${ }^{31}$.

The eleventh monthl I I mmm $\odot$ Abd 3 Smwipt-Hmt(Epip)

- The most important is related to Hathor and the goddess Mut.

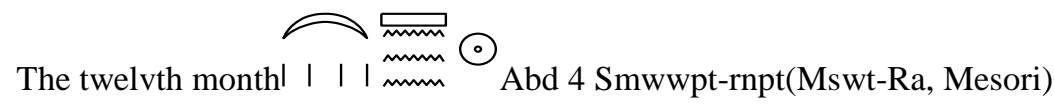

- The feast of Raet, and that of Hathor.

The last 5 days of the year were festivals for the birthday of 5 gods (July 14-18), those of Osiris, Horus the elder, Seth, Isis and Nephthys. Because of potential danger during this transitional period, Egyptians focused on protective rites for their observances where people drew protective charms of deities and magical figures onto white linen to wear around their necks and in temples, torches were kept lit to drive away evil forces ${ }^{34}$.

Outside the ancient Egyptian annual calendar was an important celebration related to the kings' rejuvenation, which is considered as a political festival, the so called $\mathrm{Hb}$-sd festival celebrated after 30 years of their rule, although evidence shows that it can be celebrated more frequent in a king's life. Also there was personal or individual festivals as the annual celebration that was established by king Ramesses III to honor his victory over the Libyans, and festival of king Amenhotep I for Deir el Medina workforce.

\title{
2.4 Ancient Egyptian festivals and modern ceremonies (mouleds):
}

The present day for the annual renewal festival is "Mouled", literally meaning "renewed" birthday. All present-day mouleds (except for Mohammed's and those of his immediate family) are continuation of Ancient Egyptian festivals, camouflaged under Islamic names ${ }^{25}$. The similarities between ancient and present traditions indicate that the modern ceremonies are pre-Islamic and pre-Christian in origin, celebrated at the new or full moon ${ }^{25}$. For example, the first drop that falls into the Nile (Isis tear), to begin the annual flood season, is recognized in northern Cairo as "Mouled el Embabi"25. Also at the end of the wag festival, which signifies that the river Nile has risen to its greatest height or nearly so, a same festival / Mouled continues to be celebrated at the same time called "Mar Barsoum el Rayan Festival" or "Mohammed Barsoum Festival", As an extension of the ancient Egyptian traditions, numerous mouleds are held throughout Egypt during the Easter holy week by the Egyptians Sufis, one of these events is the annual mouled of AbuHareera, which is held in Giza ${ }^{25}$. 


\subsection{The proposal for revitalizing three festivals}

As explained previously, most of the festivals related to the gods are similar in regards to the idea of the removal of the statues of the gods from the sanctuary of a temple, to the outside of the temple, carried by priests in special barks to be seen by the people. Transported, whether in land or the Nile mass of people presented special offerings in a ceremonial atmosphere. As a result researchers found it appropriate to focus on three different festivals to present diversity in the celebrations, as follows:

\section{1- The Opet Festival.( Religious)}

2- Osiris festival at Abydos, only in regards to the recreation of the story of murder and resurrection of Osiris by the temple staff.(Religious Drama)

3- The Hb-sd festival of the king.( Political)

\section{The Opet- festival}

It was the longest in celebration in the Theban festival calendar and was apparently considered the most important ${ }^{[39]}$. It was celebrated during the second month of the inundation season. In this festival, Amun's statue was taken out of its temple in Karnak and placed on a sacred gilded barge decorated with heads of rams, the barge was tied to sailing ships towed by a crew of men travelling upstream about 1 mile to Amun's other temple at Luxor, where it remained there for days. When the statue returned to Karnak, a similar procession and festival took place. In later times, a second barge was added which transported the statues of Amun's wife Mut and their child Khonsu ${ }^{29}$. In earlier celebrations of this festival, the statues of the gods proceeded down the avenue of the sphinxes that connect the two temples stopping at specially constructed chapels en route ${ }^{39}$.

\section{Osiris festival}

His murder and resurrection were dramatically recreated by the temple staff in the temple of Abydos, where massive crowds made their way to Abydos to witness the great spectacle ${ }^{29}$. The legend of Osiris relates to Osiris, who was a good king of Egypt; he was married to his sister Isis. Osiris taught the people agriculture and civilized them. Out of jealousy, his evil brother Seth, during a feast shut him into a wooden chest and casted it into the Nile. According to some accounts, Osiris was drowned, according to others; Seth cut Osiris body into pieces. The goddess Isis and Nephtys, according to the version of the myth of Plutarch, was found in Byblos. Seth stole the body and cut it into pieces and spread it all over Egypt. Isis discovered the parts and by the help of Anubis, became mummified. By a miracle Osiris impregnates Isis and she gave birth to Horus who grows up and avenged his father ${ }^{[40]}$. This festival is known from Middle Kingdom texts, as the Ikhernofret Stela and a great number of private stelae also the rooftop chapels of the temple of Hathor at Dendara provides a full account of this festival ${ }^{31}$. Festivals of Osiris were enacted for more than two thousand years, from Middle Kingdom to Roman era ${ }^{31}$. The Koiak festivals were celebrated throughout the country and was not restricted to those sites originally linked to the myth ${ }^{31}$. The public participated in the festivals of Osiris through their observation of the procession and through the creation and manipulation of images of the mummiform god. These images were made of variety of materials but most commonly of soil symbolizing the fertility of the land ${ }^{31}$.

\section{The Hb-sd festival}

The five day celebration of the $30^{\text {th }}$ year of a pharaoh's reign was depicted in the step pyramid of Djeser in Saqqara, in the southern tomb area. Djeser was portrayed running a race, being crowned, sitting on the throne of Lower Egypt, and then to the throne of Upper Egypt, dispensing gifts to the local priesthoods. The Hb-sd demonstrated a ruler's vigor after three decades ${ }^{28}$. The court for the sd festival at Saqqara has 2 B-shaped platforms which were turning marks for the king's ritual run. Further to the east stands the sd-court, lined on the east and west with three chapels emblematic of shrines of the north, the south and a combined form. The ornate chapels are counterfeit, made only for the soul of the deceased king to enact the as-ceremony ${ }^{[41]}$.

\section{Thus these three festivals were chosen for the following reasons;}

1- The three festivals are well known festivals in ancient Egypt.

2- The three festivals represent different celebration details.

3- The three festivals are related to different places (even though the Hb-sd is not related to a specific place but researchers aim to revitalize it in Saqqara taking benefit of the $\mathrm{Hb}$-sd court in the step pyramid complex).Thus we have 3 different places: Thebes/ Luxor (Opet festival) - Abydos (Osiris festival) - Saqqara (Hb-sd festival), Two locations in the south and one in the north, which are appropriate for tourists attraction. Also these 3 locations are already included in tourists programs in Egypt.

4- The documents relating to these three festivals are plenty and detailed, compared to other festivals that have little information. So it is easy to revitalize them, returning to the sources. 
5- The three festivals could be revitalized easily with controlled expenses, as for the two festivals of Osiris (the play) and the $\mathrm{Hb}$-sd ceremony are limited to Abydos temple and the step pyramid complex that could be organized in the form of an open theatre for audience. In the case of the Opet festival, it also includes a limited area of celebration compared to other festivals. The Opet festival as explained previously, includes a distance of around $2 \mathrm{Kms}$ (by comparing the distance of a festival like the festival of the sacred marriage of Horus and Hathor, between Dandara and Edfu, or even the feast of the valley, between the east and west bank of Thebes, and then between the bank of the river and the sites which needs various transportations and expenses). Thus, the Opet festival is appropriate for tourists on foot either by watching the ceremony live or on huge screens along the way between Karnak and Luxor temples with commentary like in the sound and light shows.

6- The three festivals events could be organized in 3 different timings of the year for tourists attraction, especially that originally 2 of them at least have different timings: The Opet festival was celebrated as stated before during the second month of the inundation (estimated in September), while the festivals of Osiris were held in the fourth month of the inundation (estimated in November). The hb- sd festival was not related to a specific timing but could be organized in March or April, so that we could have a wider festival agenda for tourists.

\subsubsection{The proposed idea for the Opet- festival:}

Place; At Luxor, in Karnak and Luxor temples.

Date; September, (according to original date).

Duration; If possible during a week, 3 hours daily every afternoon (4 to 7).

The proposed ceremony; starting point (gathering point) at Karnak temple, where guides are asked to explain the festival in different languages so that the tourists have an idea of what they are going to see. The crowd will be directed towards the avenue of the sphinxes that connected the Karnak temple with Luxor temple. At the avenue of the sphinxes, huge screens are proposed to display the procession of carrying the sacred barks with the sacred statues with sound effects and little commentary. A second stop is proposed in the temple of Luxor, explaining the rest of the procession.

\subsubsection{The proposed idea for the festival- play of Osiris:}

Place; At Abydos, in the temple of Abydos open- court.

Date;November, ( according to original date).

Duration; If possible, during a week, 4 times a day, 2 shows in the morning and 2 shows in the afternoon. Duration of the show around 1 hour and half.

The proposed ceremony: In the form of a play describing the events of the story of Osiris until his resurrection. No words are necessary just silent acting to avoid the translation in various languages.

\subsubsection{The proposed idea for the festival of the $\mathrm{Hb}$-sd}

Place; At Saqqara, in the step pyramid complex of king Djeser, Hb-sd open- court.

Date; In March or April.

Duration; If possible during a week, 6 times a day, 3 shows in the morning and 3 shows in the afternoon . Duration of the show around 1 hour.

The proposed ceremony: A half circle theatre (Roman amphitheatre) is suggested in the Hb-sd court , where a documentary film is recorded on screens or real orientation of the show. Simple words are only necessary to avoid the translation in various languages.

\section{3-Methodology of the study}

After displaying the historical importance of the ancient Egyptian festivals and the proposal of three festivals, the next part will identify the problem of the study, its aims. An exploratory study was conducted to know opinions of travel agencies, Tourists Authority and tourists in relation to the possibility of the application of the aims of the study.

\subsection{Problem of the study}

Egypt is an important destination, it attracted millions of tourists yearly, and unfortunately this was highly affected lately due to the political changes. This led to the idea of attracting tourists again by innovations in touristic programs to Egypt by including festivals as a main tourists' destination .Connecting other tourists' destinations in the country with festivals can similarly lead to tourists attraction and increase the number of tourists.

\subsection{Aims of the study}

This paper aims at:

3.2.1- Drawing attention to the touristic and historical importance of festivals. 
3.3.2-Proposing an idea of revitalizing three of these festivals.

3.2.3-Drawing attention of travel agencies to involve festivals as a main tourist attraction.

\subsection{4-Investigating the possibility of considering festivals as a main tourist attraction.}

3.2.5-Focusing on the important role of tourists authority in organizing festivals.

\subsection{Data collecting:}

This research depended on two types of data, the first provided by books and articles, and the second by three designed questionnaires distributed among: travel agencies, Tourists Authority (Ministry of Tourism, General authority for tourism promotion), and tourists. The level of agreement or disagreement with a given item is rated on a five-point Likert scale. The questionnaires were approved by a group of seven members of experts and academics. The $1^{\text {st }}$ questionnaire was destined to travel agencies that have web-sites, it was divided into five main parts as follows: The first part includes the travel agencies opinion of depending on festival events as a main tourist attraction (travel agencies opinion regarding festival events in general as a main tourist attraction, the possibility of depending on festival events in Egypt as a main tourist attraction and including festival events in the touristic agenda in Egypt ). The second part includes travel agencies opinion of involving festival events in tourists programs (Travel agencies could organize special programs to attend festival events and could include festival events in touristic programs in Egypt).The third part included the information of the travel agencies concerning festivals (Travel agencies have sufficient information concerning ancient festivals, information concerning timing of these festivals and places). The fourth part includes the expectations of travel agencies to the role provided by the tourist authority in organizing the events and providing facilities and promotion needed for these events to involve them in a yearly tourist agenda in Egypt (Tourist authority role in regards to the promotion of festival events and to facilities needed for such events). The fifth part includes the expectations of travel agencies to the impact of festivals on tourists (I expect that tourists who participate in festival events will re-participate another time and I expect that tourists who participate in festival events will advise others to participate).The $2^{\text {nd }}$ questionnaire was destined to tourist authority in Egypt to stand on their opinion concerning the possibility of depending on festival events as a main tourist attraction and their cooperation and contribution to these events. The questionnaire included the same five parts of the previous questionnaire but destined to the tourist authority. The $3^{\text {rd }}$ questionnaire was destined to tourists who dealt with travel agencies before to ask them if they are interested in such events and if they are willing to return to participate in case of organizing them and encouraging others to do the same (almost the same sentences that are shown in the previous questioners).

\subsection{Sample of the Study}

The sample included three categories: Tourists Authority (Ministry of Tourism-The General Association for Tourism Promotion), travel agencies with Web-Sites and tourists. The Questionnaires were distributed through e-mails to Tourists Authority and travel agencies and were destined to decision makers (managers).The questionnaires were distributed among 30 travel agencies with Web-Sites (2 Managers in every agency except two agencies had 1 decision maker). A total of 58 questionnaires all returned with a percentage of (100\%). In regards to Tourists Authorities, 5 questionnaires were distributed among decision makers in the Ministry of Tourism in Cairo, besides 18 questionnaires distributed among 18 Associations for tourists promotion all over Egypt with $100 \%$ reply. Tourists' questionnaires were distributed through e-mails by travel agencies among a random sample of tourists who dealt with these agencies before. 275 questionnaires were distributed among tourists, where only 206 were responded, with a percentage of $75 \%$.

\subsection{Limits of the Study}

The study included only travel agencies with Web-sites, and only tourists who dealt with these agencies before through e-mails (tourists who came to Egypt before to be able to know what to expect). The questioners were distributed between $10^{\text {th }}$ May2013 till $10^{\text {th }}$ September 2014.

\section{4- Results of the study}

\subsection{Data analysis}

Table 1 shows that there is significant differences concerning the opinion of travel agencies and tourists authority about festivals as a main tourist attraction, where $\mathrm{P}$ value $<0.05$. That means that both travel agencies and tourists' authority are enthusiastic for the idea of festivals in attracting tourists, but could not depend on it as a main tourist attraction. Through comparing the averages, clear is the positive attitude of Tourists Authority, where the average reached 2.65 and 2.33 consequently. Regarding the festivals as a main tourist attraction, the sample of travel agencies showed concern in adopting this attitude. Also this positive attitude from Tourists Authority appeared in including festivals in touristic agenda in Egypt, where the average reached 3.65, which indicates acceptance to adopt this attitude in the future. The table shows that there is no significant difference between the opinion of tourists' authority and travel agencies, sample of the study concerning organizing special programs for festivals or including them in an already organized program. But comparing the averages, revealed a higher positive attitude of Tourists Authority and Travel agencies in including festivals in an already organized program where the averages reached 3.81, 3.80 Respectively regarding information concerning historical background or timing or place of these festivals, there is no significant 
difference between Tourists Authority and travel agencies, the evident lack of sufficient information about festivals would require a group of specialists in history and training of guides. In relation to the role of Tourists Authority in organizing these events, there is no significant difference between travel agencies and Tourists Authority, both showed a positive attitude towards promotion of festivals, and providing facilities and other services.

Table (1): Comparison between the travel agencies and tourists authority regarding their opinion towards festival events as a main tourist attraction.

\begin{tabular}{|c|c|c|c|}
\hline Statement & $\begin{array}{c}\text { Travel } \\
\text { agencies } \\
\text { "n=58" }\end{array}$ & $\begin{array}{l}\text { Tourist authority } \\
\qquad " n=23 "\end{array}$ & $\mathbf{P}$ \\
\hline \multicolumn{4}{|l|}{$\begin{array}{l}\text { Opinion concerning festival events as a main tourist } \\
\text { attraction: }\end{array}$} \\
\hline $\begin{array}{l}\text { - Opinion concerning festival events in general as a main } \\
\text { tourist attraction. }\end{array}$ & $1.11 \pm 1.03$ & $2.65 \pm 1.11$ & $<0.05^{*}$ \\
\hline $\begin{array}{l}\text { - Opinion concerning the possibility of depending on festival } \\
\text { events in Egypt as a main tourist attraction. }\end{array}$ & $1.26 \pm 1.07$ & $2.33 \pm 1.84$ & $<0.05 *$ \\
\hline $\begin{array}{l}\text { - Opinion concerning including festival events in the touristic } \\
\text { agenda in Egypt. }\end{array}$ & $2.58 \pm 1.22$ & $3.65 \pm 1.18$ & $<0.05^{*}$ \\
\hline \multicolumn{4}{|l|}{$\begin{array}{l}\text { Opinion concerning organizing special programs to attend } \\
\text { festival events or including them in touristic programs }\end{array}$} \\
\hline $\begin{array}{l}\text { - - Travel agencies could organize special programs to attend } \\
\text { festival events. }\end{array}$ & $2.52 \pm 1.20$ & $2.65 \pm 1.65$ & $>0.05$ \\
\hline $\begin{array}{l}\text { - Travel agencies could include festival events in touristic } \\
\text { programs in Egypt. }\end{array}$ & $3.81 \pm 0.98$ & $3.80 \pm 1.07$ & $>0.05$ \\
\hline \multicolumn{4}{|l|}{ Information concerning festivals } \\
\hline - There is sufficient information concerning ancient festivals. & $1.68 \pm 0.98$ & $1.88 \pm 1.21$ & $>0.05$ \\
\hline $\begin{array}{l}\text { - There is sufficient information concerning timing of these } \\
\text { festivals. }\end{array}$ & $1.58 \pm 0.71$ & $1.91 \pm 1.36$ & $>0.05$ \\
\hline $\begin{array}{l}\text { - There is sufficient information concerning places of these } \\
\text { festivals. }\end{array}$ & $1.98 \pm 0.82$ & $2.11 \pm 0.98$ & $>0.05$ \\
\hline \multicolumn{4}{|l|}{ Tourists authority role in organizing festival events } \\
\hline $\begin{array}{l}\text { - Tourist authority role concerning the promotion of festival } \\
\text { events. }\end{array}$ & $3.22 \pm 1.08$ & $3.68 \pm 1.14$ & $>0.05$ \\
\hline $\begin{array}{l}\text { - Tourist authority role concerning facilities needed in such } \\
\text { events. }\end{array}$ & $3.23 \pm 1.05$ & $3.42 \pm 1.06$ & $>0.05$ \\
\hline \multicolumn{4}{|l|}{ Impact of festivals on tourists: } \\
\hline $\begin{array}{l}\text { - I expect that tourists who participate in festival events will re- } \\
\text { participate another time }\end{array}$ & $3.11 \pm 1.01$ & $3.25 \pm 1.07$ & $>0.05$ \\
\hline $\begin{array}{l}\text { - I expect that tourists who participate in festival events will } \\
\text { advise others to participate }\end{array}$ & $2.98 \pm 1.11$ & $3.55 \pm 1.44$ & $>0.05$ \\
\hline
\end{tabular}


Finally, the table shows that there are no significant differences between the opinions of Tourists Authority and travel agencies concerning the impact of festivals in attracting tourists and recommending it to others, a matter which will lead to the increase of number of tourists visiting Egypt.

Table 2: Opinion of Tourists in regard to festivals as a main tourist attraction or including it in other programs

\begin{tabular}{|c|c|c|}
\hline Statement & Mean & S.D. \\
\hline I think that festival events in general could be a main tourist attraction. & 2.11 & 1.03 \\
\hline $\begin{array}{l}\text { I think it is possible to depend on festival events in Egypt as a main tourist } \\
\text { attraction. }\end{array}$ & 2.08 & 1.11 \\
\hline $\begin{array}{l}\text { I think Travel agencies could include festival events in the touristic agenda } \\
\text { in Egypt. }\end{array}$ & 2.85 & 0.98 \\
\hline Travel agencies could organize special programs to attend festival events. & 3.28 & 0.98 \\
\hline $\begin{array}{l}\text { Travel agencies could include festival events in touristic programs in } \\
\text { Egypt. }\end{array}$ & 3.20 & 1.07 \\
\hline Travel agencies have sufficient information concerning ancient festivals. & 2.01 & 0.98 \\
\hline $\begin{array}{l}\text { Travel agencies have sufficient information concerning timing of these } \\
\text { festivals. }\end{array}$ & 1.98 & 0.92 \\
\hline $\begin{array}{l}\text { Travel agencies have sufficient information concerning places of these } \\
\text { festivals. }\end{array}$ & 2.11 & 1.07 \\
\hline Tourist authority does its role in regard to the promotion of festival events. & 1.52 & 0.85 \\
\hline Tourist authority does its role in regard to facilities needed for such events. & 2.00 & 0.81 \\
\hline $\begin{array}{l}\text { Tourist authority does its role in regard to offer the appropriate insurance } \\
\text { needed for such events. }\end{array}$ & 2.17 & 0.98 \\
\hline $\begin{array}{l}\text { I expect that tourists who participate in festival events will re-participate } \\
\text { another time }\end{array}$ & 3.98 & 1.05 \\
\hline $\begin{array}{l}\text { I expect that tourists who participate in festival events will re-participate } \\
\text { another time but in case of providing more activities }\end{array}$ & 3.58 & 1.65 \\
\hline $\begin{array}{l}\text { I expect that tourists who participate in festival events will advise others to } \\
\text { participate }\end{array}$ & 3.89 & 1.11 \\
\hline
\end{tabular}

An evaluation was done in regards to tourists' opinion of festival-events as a main tourist attraction. Descriptive analysis was used to give an insinuation to travel agencies and Tourists Authority about the extent to which the tourists accept the idea of festivals as a main tourist attraction. Table 2 also shows that it is possible to depend on festivals as a main tourists attraction, where the average of those who accepted the idea was 3.28, but there was a concern regarding the role of travel agencies and Tourists Authority in organizing such events. This requires a great effort from Tourists Authority to gain tourists credibility, especially that a lot of the sample was positive in attending these festivals and in case of their success recommending it to others. Additionally it will require continuous renovations of these festivals and benefit from others who have experience in the management of these festivals. 
Table (3): Regression analysis of different items of the questionnaire for travel agencies, Tourists authority and tourists

\begin{tabular}{|c|c|c|c|c|c|c|}
\hline & \multirow{2}{*}{ Model } & \multicolumn{2}{|c|}{ Unstandardized Coefficients } & \multirow{2}{*}{$\begin{array}{c}\begin{array}{c}\text { Standardized } \\
\text { Coefficients }\end{array} \\
\text { Beta }\end{array}$} & \multirow{2}{*}{$t$} & \multirow{2}{*}{ Sig. } \\
\hline & & B & Std. Error & & & \\
\hline \multirow{5}{*}{1} & (Constant) & 12.359 & 1.101 & & 11.221 & 0.0001 \\
\hline & $\begin{array}{l}\text { Opinion concerning festival } \\
\text { events as a main tourist } \\
\text { attraction. }\end{array}$ & 1.040 & 0.197 & 0.240 & 5.274 & 0.001 \\
\hline & $\begin{array}{l}\text { Travel agencies opinion in } \\
\text { organizing special programs } \\
\text { to attend festival events or } \\
\text { including them in touristic } \\
\text { programs }\end{array}$ & 0.961 & 0.157 & 0.304 & 3.121 & 0.021 \\
\hline & $\begin{array}{l}\text { The information of travel } \\
\text { agencies concerning festivals }\end{array}$ & 1.004 & 0.158 & 0.315 & 3.344 & 0.022 \\
\hline & $\begin{array}{l}\text { Tourists authority role in } \\
\text { organizing festival events }\end{array}$ & 1.257 & 0.146 & 0.439 & 4.620 & 0.001 \\
\hline
\end{tabular}

Regression Analysis was used to understand what factors had the highest impact on the success of festivals as a main tourist attraction. Table 3 reveals that the most important factor for the success of the idea of this study in the tourists questionnaires is the adoption of the main idea of the study which is depending on the festivals as a main tourists attraction, since the significant level was .001 , and $t$-test 5.3 , these values confirm the acceptance of Tourists Authority and tourists of the idea, in spite of the concern of travel agencies. The factor of "Tourists Authority role in organizing festival events", showed the same importance of the idea of this study. This shows the great effort expected from Tourists Authority in organizing these events. The information factor came in the $3^{\text {rd }}$ place, followed by the factor of organizing travel agencies programs mainly for festivals or as part of already organized programs. This also shows that tourists are ready to attend such festivals whether it was part of a program or as a main tourist program.

\subsection{Conclusion and Suggestions}

From this study, clear is the importance of the festivals and the role it can play in attracting tourists. As mentioned there are plenty of ancient Egyptian festivals that are worth studying and this paper attempted to propose the revitalization of only three as a start to draw attention to other festivals. But in order to accomplish this, a lot of effort is expected from Tourists Authority and travel agencies. Thus, a group of recommendations is suggested to help the tourism situation in Egypt. The recommendations are divided into two groups: the first to travel agencies and the second to Tourists Authority.

\subsubsection{Recommendations to Travel Agencies:}

- The necessity of continuous renovations in touristic programs as the new program of festival events.

- Accepting some risks in adopting new ideas for attracting tourists and involving these ideas in programs.

- Travel Agencies should provide itself with sufficient information concerning festivals, whether historical information or timing and places of these festivals with the aid of specialists in the field.

- Cooperate with Tour guides in regard to details concerning the organization of these festivals and including them in tourists programs.

- Travel Agencies should recommend tour guides to provide themselves with historical information needed for these festivals

- Travel Agencies are recommended to organize training programs for its employees involved with marketing, Programs-Planners, and tour guides to provide them with all sufficient information about festival events before including them in the tourists programs.

- Continuous evaluation of these festivals through feedback from tourists. 
- Importance of communication with Tourists Authority to provide a high level of service.

- Collaboration with Tourists Authority and Governorate to inform them through tourists' feedback of the facilities and services needed for improving these festivals.

- Benefit from tour guides who could be a valuable feedback for the success of these festivals. -

\subsubsection{Recommendations to Tourists Authority:}

- Providing all necessary help for travel agencies to adopt new ideas.

- Providing all necessary facilities for organizing these festivals to reach the required level for tourists and travel agencies.

- Organizing programs for the promotion of festivals as a main tourist's attraction.

- Gathering sufficient information about these festivals and the study of revitalizing more in case of their success.

- Involving these festivals in the touristic agenda of Egypt and in promotion books and pamphlets of the Ministry of Tourism and the General Association for Promoting tourism.

- Cooperation with all authorities and Ministries involved as the Ministry of Culture and the Governorates.

- Collaboration with travel agencies in organizing training programs and increasing awareness of locals concerning these festivals.

- Involving tour guides and locals as part of festival organization to gain their support to improve these festivals.

\section{$\underline{\text { References }}$}

${ }^{[1]}$ Congcong T. (2014), The Study of Festival Tourism Development of Shanghai, International Journal of Business and Social Science Vol. 5 No. 4.

${ }^{[2]}$ Lyck L., Long,P. and Grige A., (2012), Tourism, Festivals and Cultural Events in Times of Crisis, Copenhagen Business School Publications Published: Frederiksberg bogtrykkeri, Denmark.

${ }^{[3]}$ De Bres, K.and Davis, J. (2001), Celebrating group and place identity: a case study of new regional festival. Tourism Geographies, 3, 326-337.

${ }^{[4]}$ Gotham, K. (2005), Theorizing urban spectacles. Festivals, tourism and the transformation of urban space. City, 9, $225-246$.

${ }^{[5]}$ Markwell, K.and Waitt, G., (2009), Festivals, space and sexuality: gay pride in Australia, Tourism Geographies, 11, $143-168$.

${ }^{[6]}$ Cudny, W., (2011), Film festivals in Łódź as a main component of urban cultural tourism. Bulletin of Geography.Socio-economic Series, 15, 131-141.

${ }^{[7]}$ Cudny, W.and Rouba, R., (2011), Theatre and multicultural festivals in Lodz as a free time management factor among the inhabitants and tourists in the post-industrial city. ActaGeographicaUniversitatisComenianae, 55, 3-22.

${ }_{[8]}$ Markova, B., Bortua, T., (2012), The potential of cultural events in the peripheral ruralJesenicko region. ActaUniversitatisCarolinaeGeographica, 47(2), 45-52.

${ }^{[9]}$ Getz, D. (2008), Event tourism: definition, evolution, and research. Tourism Management, 29, 403-428.

${ }^{[10]}$ Getz, D., (2010), The nature and scope of festival studies. International Journal of Event Management Research, 5, 1-47

${ }^{[11]}$ Cudny, W., Korec, P.,andRouba, R., (2012), Resident's perception of festivals - the case study of Łódź. Slovak Sociological Review, 44, 704-728.

[12] Kowalczyk, A., (2008),Współczesnatury stykakulturowa - międzytradycją a nowoczesnością. In Kowalczyk, A., ed. Turystykakulturowa. Spojrzeniegeograficzne.

Warszawa (UniwersytetWarszawski, WydziałGeografiiiStudiówRegionalnych), pp. 9-58.

${ }^{[13]}$ Mika, M. (2007). Formyturystykipoznawczej. In Kurek, W., Faracik, R., Mika, M., Pawlusiński, W., Pitrus, E., PtaszyckaJackowska, D., eds. Turystyka. Warszawa (WydawnictwoNaukowe PWN), pp. 198-231.

${ }^{[14]}$ Quinn, B. (2010) ,Arts festivals, urban tourism and cultural policy. Journal of Policy Research in Tourism, Leisure \& Events, 2 , 264-279.

${ }^{[15]}$ Cudny, w. (2013), Festival tourism - the concept, key functions and dysfunctions in the context of tourism Geography studies, Geographical Journal 65 2, 105-118.

[16] Chen,Z; Huang,P.(2011),Festival Tourism in China, Dragon Boat Festival and Tourism.http://www.gttp.org/content/listings/88/files/12/Festival-Tourism-in-China.pdf

${ }^{[17]}$ Smith, C., JennerP., (1998). “The Impact of Festivals and Special Events on Tourism, Occasional Studies.”In Travel and Tourism Analyst, 4. London: Economist Publications.

${ }^{[18]}$ Kotler, P. D. H. Haider, and I. Rein (1993). Marketing Places: Attracting Investment, Industry and Tourism to Cities, States and Nations. NewYork: Free Press.

${ }^{[19]}$ Getz, D., (1997), Event management \& event tourism, Cognizant Communication Corp- Pennsylvania State University

${ }^{[20]}$ Alen, J., Toole. W., and Harris, R., Mcdonnell, I.,(2005),Festival and special event management, John Wiley \&Sons, Australia.

${ }^{[21]}$ Andrejević, A., Grubor, A.,(2007),Menadžmentdogađaja, Fakultetzauslužnibiznis, Novi Sad. 
${ }^{[22]}$ Vukašin Š., Dejan Đ., (2011), The place and role of events in the tourist development of the southwest Serbia Cluster, Vol. 8, No 1, pp. $69-81$.

${ }_{[23]}^{[2}$ Gardiner, A.,(1927), Egyptian Grammar.p512

${ }^{[24]}$ Bleeker, C., J., (1967), Egyptian Festivals, Enactments of Religious Renewal. Brill, Leiden.Netherlands.p31,2

${ }^{[25]}$ Gadalla, M., (2003), Egyptian Mystics: Seekers of the Way. Tehuti research Foundation USA.p.75.

${ }^{[26]}$ Spalinger, J.,(1996), The Private Feast Lists of Ancient Egypt. Ott Harrassowitz Verlag.Germany. , p.2,11

${ }^{[27]}$ Johnston, L., S., (2004), Religions of the Ancient World, A Guide. Harvard College. USA. p. 248

${ }^{[28]}$ Bunson, M., (2009), Encyclopedia of Ancient Egypt.Library of Congress.USA. p.138

${ }^{[29]}$ Ruiz, A. (2001),The Spirit of Ancient Egypt. Algora Publishing. New York. p.159

${ }^{[30]}$ Kimpton, J. F. (2012), Festivals, Pharaonic Egypt. abstract

${ }^{[31]}$ Teeter, E. (2011), Religion and Ritual in Ancient Egypt. Cambridge University Press.USA.p.56

${ }^{[32]}$ Lloyd, B. A. (2010), A Companian to Ancient Egypt. Blackwell Publishing.UK. p.533.

${ }^{[33]}$ Ellis, N. (1999), Feasts of Light: Celebrations for the Seasons of Life based on the Egyptian Goddess Mysteries.Quest edition.USA.

${ }^{[34]}$ La Borde, Sh. (2012), Circle of the Sun: Rites and Celebrations for Egyptian Pagans and Kemetics. Lulu editions.pp.95, 96

${ }^{[35]}$ Hamburg, H. A. (1977), Fest, in LAII, pp.171-191. , pp.173-180

${ }^{[36]}$ Kitchen, A. K. (1977), Festekalende, in LAII, pp.191,192). p.191

${ }^{[37]}$ Naydler, J. (1996), Temple of the Cosmos: The Ancient Egyptian Experience of the Sacred, Inner Traditions Pub. USA. p. 76

${ }^{[38]}$ White, M. J. (2012), Everyday Life in Ancient Egypt. p.134

${ }^{[39]}$ Shafer, B. E. (2005), Temples of Ancient Egypt, Cornell University Press. New York. p.158

${ }^{[40]}$ Myslivec, K. (2004), Eros on the Nile, Cornell University Press. New York. p. 56

${ }^{[41]}$ Brewer, J. D. (2014), Ancient Egypt: Foundations of a Civilization, Routledge Publications, USA. p.194

\section{مقترح لإعادة إحياء بعض الإحتفالات المصرية القديمة من أجل الجذب السياحي}

تعد الأحتفالات من الاتجاهات الحديثة التى يمكن من خلالها جذب المزيد من السياح و إضافة مز ايا تتافسية للمقاصد السياحية.ويمكن اعتبار أعياد المصريين

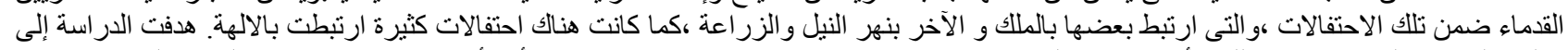

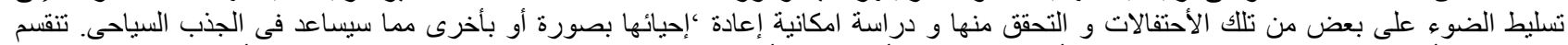

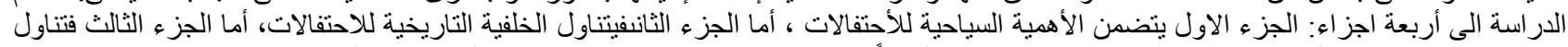

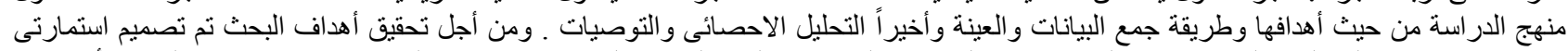

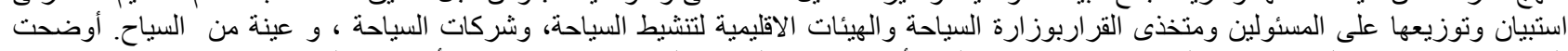

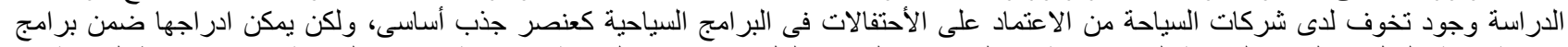

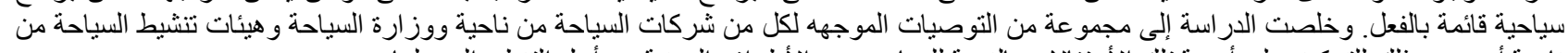
ناحية أخرى، وذلك للتركيز على أهمية تللك الأحتفالات بالنسبة للسياح ودور الأطر افت المعنية من أُجل التنظيم الجيد لهات التها. 